\title{
Universities and neglected diseases - it is not enough to have the knowledge, it must be applied
}

\author{
Caramori CA (1), Barraviera B (2)
}

(1) Internal Medicine Department and Clinical Research Unit (UPECLIN), Clinical Hospital, Botucatu Medical School, São Paulo State University (UNESP - Univ Estadual Paulista), Botucatu, São Paulo State, Brazil; (2) Department of Tropical Diseases, Botucatu Medical School, São Paulo State University (UNESP - Univ Estadual Paulista), Botucatu, São Paulo State, Brazil, and Center for the Study of Venoms and Venomous Animals, São Paulo State University (UNESP - Univ Estadual Paulista), Botucatu, São Paulo State, Brazil.

Countries located in the tropical region face public health problems such as nutritional, parasitological, bacterial and viral ones as well as accidents caused by venomous animals (http:// globalnetwork.org/files/gn-ntds-pt.pdf).

In 2006, the World Health Organization (WHO) published 14 afflictions called the neglected tropical diseases (NTDs). This publication was consolidated at the "Global Partners of the WHO" conference on NTDs which was held in Geneva on April $19^{\text {th }}$ and $20^{\text {th }}$, 2007. The NTDs afflict about one billion persons, mainly poor populations living in tropical and subtropical regions. These diseases often overlap geographically thus bringing contamination by more than one agent.

Brazil and the majority of African countries are the most affected by NTDs. Among such infections three are considered public health problems for our country, namely Chagas' disease, leishmaniasis and accidents caused by venomous animals. In April of 2009, snakebites were included in the NTDs and ranked fifteenth among them (1).

The production of new drugs to treat NTDs is insufficient in both developed and developing countries. The pharmaceutical companies constitute a highly monopolized and profitable sector that requires large investments in research and development (R\&D). Following the logic of business, high investments imply the production of profitable drugs. Given that the individuals who suffer from tropical afflictions live in developing countries, it is not difficult to understand why these diseases would also be neglected by the large pharmaceutical laboratories. Furthermore, the market share for the pharmaceutical industry in developing countries is extremely small, in other words, only $7.7 \%$ for Africa, Asia and Australia and $3.8 \%$ for Latin America. In this context, not even $2 \%$ of all R\&D investment is directed toward the development of new drugs to combat the neglected diseases (http:// www.who.int/intellectualproperty/events/ OpenForumBernardPecoul.pdf).

As only one example, the first effective pharmaceuticals against the parasite of Chagas' disease were developed about 30 years ago. Even today only two drugs continue to be the sole alternatives available, despite their high toxicity.

The same happened with leishmaniasis against which pentavalent antimonials were introduced in the 1940s and since then have been considered the drug of choice. Among the second-line drugs amphotericin $\mathrm{B}$ and pentamidine remain prominent.

As to antivenom production, it has been standardized for about 100 years and continues to be produced in the same way (2).

Animal toxins are a rich source of components with a wide spectrum of biological and pharmacological activities. According to Warrel (1), "Snake venoms are rich in protein and peptide toxins that have specificity for a wide range of tissue receptors, making them clinically challenging and scientifically fascinating, 
especially for drug design". In 2009, Lima et al. (3) dedicated an entire book to this subject, entitled Animal toxins: state of the art - perspectives in health and biotechnology. The authors discuss in several chapters the possible mechanisms and the probable uses of these molecules in the diagnosis and treatment of different diseases. In 2010, the same authors published an article in the journal Toxicon called "Toxinology in Brazil: a big challenge for a rich biodiversity" (4), showing the potential of Brazilian biodiversity as well as the imperative need for its bioprospection.

Within the scope of the immunobiologicals, historically, it was Vital Brazil who on August 14, 1901 provided the first flasks of antivenom for human treatment. Vital Brazil was the pioneer in Brazil in researching the use of toxins "in favor of human beings and other animals".

In this context, in 1989, researchers at São Paulo State University, UNESP, started to design a research center dedicated to university extension, teaching and research in the area of Toxinology. It was called the Center for the Study of Venoms and Venomous Animals (CEVAP) of UNESP, and would pursue the objective of increasing the bioprospecting of molecules from toxins and applying them for the benefit of humans $(5,6)$. At that time, the bioprospecting of fibrin sealant derived from snake venom started, because the similar product manufactured from bovine thrombin and human fibrinogen, might transmit infectious diseases. After several experiments a new sealant from the blood of large animals associated with a fraction of snake venom was standardized. In the ensuing 20 years of research, several theses and dissertations were defended, international publications and patents were produced, and amazingly, no pharmaceutical laboratory was interested in its production.

Nevertheless, Brazilian universities prepare professionals, produce scientific knowledge and collaborate in the development of science. Many University research centers are dedicated to solving national problems. They research, publish, exchange knowledge, invest in training and compete for competence in global rankings. Fortunately, in 2005 the National Network of Clinical Research (RNPC) was created by a meritorious joint action of the Brazilian Ministry of Health and Ministry of Science and Technology aimed at promoting best practices in clinical research focused on the needs of the
Brazilian population and its Single Health System (SUS). Moreover, the mission of the RNPC is to be a participating element within the productive cycle of biotechnological inputs directed more toward the needs of the country than those of pharmaceutical companies. The RNPC supports clinical trials necessary for the production of new national pharmaceuticals, principally those related to the neglected diseases. It is very important for the RNPC that the national research promote scientific knowledge which would meet the demand of public problems. The main point is to transfer knowledge from the laboratory to the patient (7). Public health, the neglected diseases, the characteristics of our populations, bioprospecting and the use of national inputs, the development of local businesses, the formation and strengthening of public-private and publicpublic national partnerships, the proper channeling of public funds, among others, must guide the approach of the university in health research.

A new paradigm is urgently needed: KNOWLEDGE PLUS ACTION to combat neglected diseases. Then ITISNOTENOUGHTO KNOW, SOMETHING HAS TO BE DONE. The University research centers must produce drugs to clinical trials. Furthermore, much research has been done without applicability in the real world. Until the $20^{\text {th }}$ century, academic medicine was developed fundamentally supported by the interests of basic research groups and industry. It was called "the century of biology". The medicine of the future demands that we be able to transfer the knowledge obtained until now, to the benefit of the world population, mainly in the area of neglected diseases (https://services.aamc. org $/$ publications/showfile.cfm? file $=$ version 58 . pdf\&prd_id=150\&prv_id=176\&pdf_id=58). University centers must produce these drugs, make them available within the national system of research networks that fight neglected diseases, such as RNPC and contribute with the government in setting up pilot production labs. These is the current scenario: if we do not act now, we will spend the next years complaining about a lack of alternatives for coping with the Brazilian neglected diseases, which kill millions of persons every year, and the laboratories will continue importing inputs and selling them at exorbitant prices without attending to our basic necessities. 


\section{COPYRIGHT}

(C) CEVAP 2011

\section{SUBMISSION STATUS}

Received: February 4, 2011.

Accepted: February 4, 2011.

Full paper published online: February 28, 2011.

\section{CORRESPONDENCE TO}

BENEDITO BARRAVIERA, Centro de Estudos de Venenos e Animais Peçonhentos, UNESP, Caixa Postal, 576, Botucatu, SP, 18618-970, Brasil. Phone/fax: +55 143814 5446. Email: bbviera@ jvat.org.br.

\section{REFERENCES}

1. WarrellAD.Snakebite.Lancet.2010;375(2708):7788.

2. Ferreira Junior RS, Nascimento N, Couto R, Alves JB, Meira DA, Barraviera B. Laboratory evaluation of young ovines inoculated with natural or ${ }^{60} \mathrm{Co}$ irradiated Crotalus durissus terrificus venom during hyperimmunization process. J Venom Anim Toxins incl Trop Dis. 2006;12(4):620-31.

3. Lima ME, Pimenta AMC, Martin-Eauclaire MF, Zingali MB, Rochat $\mathrm{H}$. Animal toxins: state of the art - perspectives in health and biotechnology. Belo Horizonte: Editora UFMG; 2009. 750 p.

4. Lima ME, Fortes-Dias CL, Carlini CR, Guimarães JA. Toxinology in Brazil: a big challenge for a rich biodiversity. Toxicon. 2010;56(7):1084-91.

5. Barros LC, Ferreira RS, Barraviera SRCS, Stolf HO, Thomazini-Santos IA, MendesGiannini MJS, Toscano E, Barraviera B. A new fibrin sealant from Crotalus durissus terrificus venom: Applications in medicine. J Toxicol Environmental Health, Part B. 2009;12(8):55371.

6. Thomazini-Santos IA, Barraviera SRCS, MendesGiannini MJS, Barraviera B. Surgical adhesives. J Venom Anim Toxins. 2001;7(2):159-71.

7. Brasil. Ministério da Saúde. Rede Nacional de Pesquisa Clínica do Brasil: respostas e redução da dependência estrangeira. Rev Saúde Públ. 2010;44(3):575-8. 